\title{
Maimonides' Arguments for Creation Ex Nihilo in the Guide of the Perplexed
}

\author{
ANDREW L. GLUCK
}

Hofstra University

\section{INTRODUCTION}

Maimonides' arguments for creation ex nihilo are a centerpiece of The Guide of the Perplexed and, like many other issues discussed in the Guide, the question of whether the universe is created or eternal is still a matter of controversy, as is Maimonides' real opinion regarding it. Then, as now, the Aristotelian theory of an eternal material universe seemed more plausible to many people than did the Biblical view of creation ex nihilo. While creation is the orthodox view in both Judaism and Christianity, the tension between those two explanatory models goes back a long way. ${ }^{1}$ Referring to the heretical views of Elisha ben Abuya, in the early Talmudic period, David Hartman argues as follows.

He therefore found it impossible to remain within a tradition based upon a false belief in creation. Maimonides attempts to prevent such lapses as Elisha's apostasy by offering the Guide as an epistemological map which leads the student along a route that integrates the claims of authority and reason. ${ }^{2}$

This is indeed an area where Maimonides felt that the claims of reason and authority must be reconciled because he indicates that he would be willing

I thank Professor (Rabbi) Henry Toledano for his invaluable assistance with some difficult passages in the Guide. His discussion of the Arabic text opened up for me completely new ways of seeing things. Despite his help, however, any conclusions (and errors) arrived at are my own.

1. Maimonides believed that prior to Abraham, the religion was Sabianism (paganism), believing in an eternal universe and worshipping the stars (Guide III, 29).

2. D. Hartman, Maimonides: Torah and Philosophical Quest (Philadelphia: J.P.S., 1976), p. 133. 
to accept Aristotle's position on the eternity of the universe a parte ante 3 if it could be shown to be demonstrable. ${ }^{4}$ He also maintains, however, that belief in creation is an essential "foundation of the Torah" and that acceptance of Aristotle's notion of eternity "destroys the Law in its principle, necessarily gives lie to every miracle, and reduces to inanity all the hopes and threats that the Law has held out."5

Maimonides states clearly that no demonstrations for or against creation exist. He is severe in his criticism of the Kalām (Muslim theologians who thought they had demonstrated the necessity of creation) and with the philosophers who thought they had demonstrated the necessity of the eternity of the universe. 6 Yet he insists that creation can be defended on rational grounds.

Maimonides invited criticism by insisting in his introduction to the Guide that he would not contradict himself except with deliberation. ${ }^{7}$ Some

3. There are two kinds of eternity, a parte ante and a parte post. The former refers to an eternal beginning (strange as it may seem), and the latter to an eternal end. One can believe in creation ex nihilo but still not believe in a finite end. Maimonides had no problem with that eternity.

4. It is usually assumed that he would have accepted a demonstrated version of the eternity thesis. He states, "if the philosphers would succeed in demonstrating eternity ... the Law as a whole would become void, and a shift to other opinions would take place." (Guide II, 25, p. 330). This seems to be a normative statement, not a descriptive one; in other places he states that the masses are not swayed by demonstrative arguments but only by persuasive ones. Perhaps they would continue to believe in the "Law" despite rational arguments against it. He also states, "Do not turn away from the opinion according to which the world is new, except because of a demonstration" (GuideII, 24). He then lays down a methodology of scriptural interpretation whereby one must reject the literal meaning of the text if contrary or contradictory propositions can be demonstrated (GuideII, 25). He gives two "causes" (grounds?) for not accepting the eternity view: the fact that it has not been demonstrated and the fact that it "destroys the Law" (Guide II, 25). It is not clear whether they are sufficient conditions for rejecting the doctrine or merely necessary conditions, whether he might accept the eternity thesis though undemonstrated if it didn't destroy the law or whether he would accept it if demonstrated though it destroys the law.

5. See the Guide, Book II, Chap. 25, p. 328. Except where explicitly stated otherwise, for this reference and all subsequent references to and quotations from the Guide of the Perplexed, see the Shlomo Pines trans. (Chicago: University of Chicago Press, 1963).

6. See the Guide, Book I, Chap. 71, p. 180: "And everyone who engages in speculation, who is perceptive, and who has acquired true knowledge of reality and does not deceive himself, knows that with regard to this question (namely the eternity of the world or its temporal creation) no cogent demonstration can be reached and that it is a point before which the intellect stops." He accuses the Kalām of assuming the truth of the content of revelation in order to "demonstrate" creation. He is particularly adamant about the mistaken attempt to ground a belief in God on a belief in creation as he believes that the existence of God can be proven even while conceding the eternity of the universe.

7. Maimonides discusses seven causes of contradictions or inconsistencies in literary works but insists that in the Guide any inconsistencies should be attributed 
have concluded that his real position was not that which he openly expressed in the Guide; some have even argued that he really accepted the eternity thesis. Their position stems from his desire to conceal esoteric truths from the masses and the fact that he seems to contradict himself in a few places in the Guide while discussing this issue. Others take Maimonides at his word even if it leaves some contradictions. ${ }^{8}$

While I view Maimonides as having esoteric views and will explore them somewhat, I will not attempt to find a completely secret position on creation and eternity (if he had one). Nor will I answer hypothetical questions about what his position would have been if he had indeed concluded that Aristotle's eternity thesis was demonstrable or even true by preponderance of evidence. ${ }^{9}$ While we can never really know the answers to those questions, we perhaps can shed some light on the matter by a close examination of his actual arguments. ${ }^{10}$

With all the scholarly interest in this subject, I have not seen Maimonides' argument for creation schematized, and it is also doubtful whether his

to the fifth or seventh cause. The fifth cause results from a necessary methodology in explaining difficult concepts. The teacher must at times make different assumptions in order to induce the student to understand. This is very interesting because we often come to understand by transcending inadequate conceptions which remain and are the cause of incongruities. The seventh cause is due to metaphysical material that must be partly revealed but partly concealed so that only those capable and worthy of understanding it will do so. It is that cause which has been focused upon by many modern critical scholars.

8. Although unconvinced by the arguments for Maimonides' supposed belief in the eternity thesis, his position may not have been as diametrically opposed to it as many have thought. Oftentimes what appear to be contrary doctrines can be integrated into a higher synthesis. For a succinct argument for Maimonides' acceptance of eternity, see Colette Sirat, A History of Jewish Philosophy in the Middle Ages (New York: Cambridge University Press, 1985) pp. 188-92.

9. According to his stated views, he should have rejected creation if the eternity thesis could be demonstrated. But people often have a way of reinterpreting things when necessary in order to preserve fundamental beliefs even if this changes the meaning of those assertions. Some say that Maimonides was only willing to reinterpret scripture when the literal meaning of the text could be demonstrated to be false. Arthur Hyman has made this assertion. See A. Hyman, "Maimonides on Creation and Emanation" in Studies in Medieval Philosophy, ed. John F. Wippel (Washington D.C.: Catholic University of America Press, 1987), p. 46. That can be questioned, however. Maimonides states that the account of creation in the Bible is not all to be taken literally without asserting that there are any demonstrable problems with the text (Guide II, 29). More explicitly, he insists that Balaam's talking ass was a prophetic vision though the literal interpretation of the text does not seem to be demonstrably false (Guide II, 42).

10. I deal mostly with his arguments in the Guide. Certain inconsistencies between those arguments and some earlier writings have been noted. There is also a great deal of medieval Jewish literature on the compatibility of rejection of creation and acceptance of the Torah. See M. Kellner, Dogma in Medieval Jewish Thought (Oxford: Oxford University Press, 1986). 
argument has been given the intensive attention that it deserves. ${ }^{11}$ That is unfortunate because many competent scholars continue to mischaracterize the argument—possibly because it was camouflaged by so many superfluous arguments. ${ }^{12}$ One may give many arguments for rhetorical purposes but if one argument is pulling all of the weight, that is the real argument from a logical perspective. In my view, the real argument was a simple one which for the religiously faithful would come close to a demonstration as he promised. In a sense it is an integration of reason and authority as Hartman has maintained. Alongside the argument there are appeals to authority or pseudo-scientific arguments, more persuasive perhaps but not resembling a demonstration. The arguments are often confused.

My position in brief is that Maimonides argues for creation ex nihilo on the basis of the fact of revelation and not on any particular authoritative, traditional opinion. ${ }^{13}$ Revelation is assumed and from that assumption everything else follows. While this will be fleshed out in greater detail, I ask the reader to reflect upon Maimonides' asserted consequence of rejecting creation and accepting eternity (a result that "destroys the Law in its principle, necessarily gives lie to every miracle, and reduces to inanity all the hopes and threats that the Law has held out" [my emphasis]).

\section{MAIMONIDES, HUMAN KNOWLEDGE OF GOD AND CREATION}

An attempt to understand what Maimonides means by creation requires a knowledge of Maimonides' view of the Creator and the limitations of human knowledge regarding Him. While entire books have been written about this, some pertinent aspects of his views will be noted here. Maimonides' view of God has been termed "Neoplatonic." He is reluctant to place the Creator in any existing ontological category such as the Aristotelian form of the universe or to allow for much positive knowledge of God. ${ }^{14}$

11. See the Maimonidean bibliography of books and articles in major European languages from 1950-1986 by David R. Lachterman in Maimonidean Studies, Vol. 1, ed. Arthur Hyman (New York: Yeshiva University Press, 1990). In this eighteen-page bibliography I found only eight publications which deal specifically with creation, eternity of the universe, or both.

12. If I can show that $2+2=4$ by logical demonstration, it is not necessary to reinforce it by arguments from authority such as: "All mathematicians agree that $2+2=4$."

13. While no hard and fast rule applies, this is consistent with the tendency among many medieval Sephardic scholars to rely upon tradition in areas of law and upon reason in areas of belief.

14. From another point of view, Neoplatonism allows for greater knowledge of God than does Aristotelianism. The Aristotelian metaphysics says little or nothing about God except for placing the deity as the form and final cause of the universe 
This "negative theology" creates problems for his normative views regarding humanity which include an intellectual approach to God who perhaps can not really be known. ${ }^{15}$ While we will not deal with that problem in any depth, it should be noted that Maimonides allows for knowledge of God in terms of sheer existence and causal relationship to the world but certainly not in terms of a divine "nature." 16 It could even be said that he is not as restrictive in attributing relationships between God and the creation as he sometimes explicitly states. For example, according to Maimonides the existence of God is certain, can be demonstrated, and the world could not exist without God's continuing to exist. ${ }^{17}$ This means that the relationship between God and the world is not purely extrinsic like the relationship between human beings and their creations but is intrinsically related to the causal structure of objective reality. ${ }^{18}$ This makes God's actions more inti-

while the Neoplatonic metaphysics allows for continuous connection (via emanation) of all levels of reality. Hence, the Neoplatonist can climb to higher and higher levels of reality. But the application of the Neoplatonic model to Judaism (as for example in ibn Gabirol) stops that process somewhere below the Godhead. Maimonides seems to recognize that the Platonic view is much closer to the Biblical concept of creation than is the Aristotelian one. The Aristotelian view allows one to view God as the form of the universe, which is a concept accessible to human reason and this expansive role for reason does not allow for skepticism. Shlomo Pines asserted that the Maimonidean negative theology "was no intrinsic or important part of the traditional Aristotelian system." See his introduction to the Guide, p. xcv. Maimonides does refer to God as the form of the universe and is insistent upon that role and that of final cause (Guide I, 69) but cautions the reader that such language cannot mean the same as its ordinary use (Guide, I, 69).

15. The problem is more religious than epistemological. The search for knowledge rarely arrives at a final truth but how does one worship a deity about Whom one knows nothing?

16. See the Guide II, 58.

17. See the Guide I, 69. For a good discussion see H. A. Wolfson, Repercussions of the Kalām in Jewish Philosophy (Cambridge: Harvard University, Press, 1979), pp. 188-89.

18. That is not to say that God's being necessarily results in the causal structure of the world as we know it but that the causal structure entails Divine activity or being. This position seems to be opposed to the view of Seymour Feldman who considers causality to be the sort of relational predicate which Maimonides prohibits from being applied to God. I believe that a careful reading of the Guide I, 52, 53 will show that by "relation," Maimonides means something quite different and that action predicates regarding God, which Maimonides allows, include what would ordinarily be considered causality. To this end, he offers the following example: "Zayd is the one who carpentered this door, built that particular wall, or wove this garment." He later states: "But you know that, regarding this subject, there is no difference between your saying a cause and your saying a maker" (see the Guide I, 52, 69; pp. 119, 167). There is a great deal of truth in Feldman's position if "causality" is interpreted narrowly enough but we cannot adequately discuss causality here. Feldman faults certain Christian Scholastics for misinterpreting Maimonides and states: "Nor did we find in Maimonides any examples of the schema 
mately connected to His Being than are the actions of human beings to the human essence. 19

Maimonides uses the Aristotelian concept of the relationship of form to matter as a model for understanding the relationship between God and the universe while cautioning that the true relationship is not really the same. ${ }^{20}$ In the Guide II, 12, Maimonides even attempts to describe his Neoplatonic emanationist view. The best interpretation that I have found is that of Alexander Altmann: "For Maimonides the flow of emanations that results in the bestowal of forms upon matter in the physical world is identical with the flow of emanations that constitutes the exercise of Providence and the gift of prophecy." 21 This is an esoteric view that, according to Maimonides, is best described as an overflow as from an overflowing spring. ${ }^{22}$ Although this is not the popular or naïve view of creation, he apparently thought that it and the eternity thesis were mutually exclusive. What emerges is a fairly detailed description of God's

"God is $\varnothing$ because He causes $\varnothing$ in creatures." See S. Feldman, "A Scholastic Misinterpretation of Maimonides' Doctrine of Divine Attributes," Journal of Jewish Studies 19 (1968): 23-29. Feldman is correct if one searches for the most literal rendition of that formula in the Guide. But I did find something strongly resembling that formula (Guide I, 54, p. 125): "It thus has become clear to you that the ways and characteristics are identical. They are the actions proceeding from God, may he be exalted, in reference to the world. Accordingly, whenever one of His actions is apprehended, the attribute from which this action proceeds is predicated of Him, may he be exalted, and the name deriving from that action is applied to Him. For instance, one apprehends the kindness of His governance in the production of the embryos of living beings, the bringing of various faculties to existence in them and in those who rear them after birth faculties that preserve them from destruction and annihilation and protect them from harm and are useful to them in all the doings that are necessary to them. Now actions of this kind proceed from us only after we feel a certain affection and compassion, and this is the meaning of mercy. God, may he be exalted, is said to be merciful, just as it is said, Like as a father is merciful to his children, . . . It is not that God, may he be exalted, is affected and has compassion. But an action similar to that which proceeds from a father in respect to his child and that is attached to compassion, pity, and an absolute passion, proceeds from Him." Maimonides refers here to the production by God of caregivers as a justification for attributing the attribute of mercy to Him. Hence, He is merciful because He causes mercy in creatures.

19. Whatever God does is a completely free and knowledgeable decision whereas human beings are the victims of ignorance and powerlessness. But only created things have essences.

20. Guide I, 69, p. 169. Maimonides, perhaps incorrectly, interprets Aristotle's God of the Metaphysics to be imbedded in matter. That might have been Aristotle's prior opinion in earlier writings such as On Philosophy. For a good discussion see the "Aristotle" article by G. B. Kerferd in The Encyclopedia of Philosophy, vols. (New York: Macmillan Publishing, 1967), 1:160-61.

21. A. Altmann, "Maimonides and Thomas Aquinas: Natural or Divine Prophecy?" in Essays in Jewish Intellectual History (Hanover, N. H. Brandeis University Press, 1981), p. 82.

22. Compare with Shelomo ibn Gabirol's Mekor Hayim (Spring of Life). 
relationship to the material universe combined with an utter ignorance of His essential being. ${ }^{23}$

The limitations on essential knowledge of God play a role in the argument for creation and the kind of creation that he is arguing for. On the one hand, he claims to argue for a Biblical view of creation but his view of the Creator and the limitations that he sets on such knowledge makes it impossible for him to fully support the Biblical account. For Maimonides, divine "actions" seem to be emanations no matter how much he insists upon creation as a free act of God. Hence, his view is essentially neither creation nor eternity even if he ultimately comes down in favor of the former. There is tension here between three aims: support of the Biblical account, a Neoplatonized Aristotelian view of the relationship between form and matter and between God and the universe, and a pious Neoplatonic ignorance regarding God. The result seems to be esotericism hidden behind traditional views.

\section{ETERNITY IN THE THOUGHT OF ARISTOTLE AND MAIMONIDES}

In the Aristotelian view, time is dependent upon the motion of physical objects. For Aristotle, eternity of the universe means time without beginning or end, a view not acceptable to Maimonides. Nor was the literal meaning of the Biblical account of creation acceptable. The Bible speaks about time prior to the formation of the heavenly bodies but time is linked to the movement of the earth vis-à-vis the sun. The Bible depicts God performing acts of creation on days one, two, and so forth, but God is beyond time and one cannot qualify God's acts in terms of time which is a created accident. ${ }^{24} \mathrm{He}$ argues, therefore, for knowledge of God based solely on His acts, which are known in a temporal dimension but essentially have nothing to do with time because they are emanations. We may recognize a similarity with certain views of Aristotle. Maimonides attributes to Aristotle the belief that the second intellect proceeds from the first and the first from

23. For a very good discussion of the subject of negative theology in Maimonides and Aquinas, see Isaac Franck, "Maimonides and Aquinas on Man's Knowledge of God: A Twentieth Century Perspective," in Maimonides: A Collection of Essays, ed. Joseph A. Buijs (Notre Dame, Ind.: University of Notre Dame Press, 1988), pp. 284-305. Although the article is biased in favor of negative theology and glosses over ethical and other normative problems, it includes some good analysis.

24. "The purpose however is that, according to us, time is a created and generated thing, as are the other accidents and the substances serving as substrata to these accidents. Hence God's bringing the world into existence does not have a temporal beginning, for time is one of the created things. Consider this matter thoroughly" (Guide II, 15, p. 282). 
God, insisting that Aristotle did not mean there was temporal succession or efficient causality but some other kind of necessary causality. ${ }^{25}$ Aristotle's eternal universe may not be what it appears at first blush and neither perhaps is Maimonides' creation. ${ }^{26}$

\section{MISTAKEN VIEWS REGARDING THE ARGUMENT}

One purpose of this article is to show that Maimonides' views are often misunderstood. In the Universal Jewish Encyclopedia, one finds this opinion in the article entitled "Creation":

Maimonides does not attempt to demonstrate the truth of the idea of creation on any logical ground. He states that it cannot be proved, and that it is a matter of belief. Nor is it an essential belief of Judaism or definitely taught in the Bible; he says that if he were to accept the theory of the eternity of matter, he could explain away the Biblical word bara, "create" as meaning "to shape" matter that had already existed. 27

The author was perhaps mistaken is supposing that creation is not "an essential belief of Judaism" and not "definitely taught in the Bible." He was surely mistaken in denying to the doctrine "any logical ground." We will attempt to ascertain how such errors arise.

In the Encyclopedia Judaica article on creation some statements also raise questions.

Maimonides does not find the proofs of the Kalām convincing. . . Moreover, he rejects the Neoplatonic accounts of creation. On the other hand, he argues that neither Aristotle nor his Muslim followers have succeeded in demonstrating the eternity of the universe. Hence, the issue cannot be decided on philosophical grounds alone. For Maimonides, however, it must be decided, since to adopt the eternity hypothesis is tantamount to the claim that the universe and its laws necessarily emanate from God. The belief in miracles implies, however, that God can freely interrupt the course of nature. Thus the

25. See the Guide II, 21, p. 316.

26. In the Guide II, 2, Maimonides states that the "strongest proofs" for creation involve the existence of the separate intellects, which he identifies with the Biblical angels. He does not explain this further. One suspects he is alluding to the esoteric emanationist doctrine previously alluded to which can never be explicitly stated and can be grasped only after years of study and contemplation. Perhaps the conceptual gap between creation and eternity can be bridged by a theory of emanation involving separate intellects, but for Maimonides, the universe (and time) did not always exist; their existence is to be explained by a free (not necessary) act of God.

27. The Universal Jewish Encyclopedia, 10 vols. (New York: The Universal Jewish Encyclopedia, Inc., 1941), 3:396. 
question of creation is especially perplexing: it must be decided, but philosophy cannot resolve it. . . . At this point Maimonides appeals to revelation. 28

In that excellent article, Seymour Feldman seems to equate "philosophical grounds" with demonstrative arguments but few philosophical disputes have been amenable to such foolproof arguments. There are non-demonstrative (dialectical) methods in the Aristotelian tradition. For Aristotle, dialectics is a discipline intermediate between demonstrative science and rhetoric; it is not certain knowledge nor is it mere persuasive opinion. If philosophical arguments ought to be demonstrations, Aristotle's rambling discussions in the Metaphysics and other works would make no sense and much philosophy would be nonsense. It is true that for Aristotle the most perfect scientific knowledge is demonstrative, but he also uses the term "knowledge" for lower degrees of clarity and certainty. ${ }^{29}$ Dialectical arguments, historically, were sometimes approved of and sometimes not; they never constituted an ideal. But Aristotle states in the Topics that dialectics is useful "because the ability to raise searching difficulties on both sides of a subject will make us detect more easily the truth and error about the several points that arise," and has further use as a "process of criticism wherein lies the path to the principles of all inquiries" 30 Hence, despite the superiority of demonstrative arguments, the less certain process of dialectics is essential to truth seeking. Maimonides, as we will see, thought that much of Aristotle's science was not demonstrative. He also recognized that Aristotle's argument for eternity was not demonstrative yet praised it as superior to other views in contention. Maimonides, therefore, was not of the opinion that the only good philosophical ground for accepting a proposition is a demonstrative proof though he considered it the best philosophical ground. ${ }^{31} \mathrm{H}$. A. Wolfson thought that Maimonides' argument for creation was not demonstrative nor based on revelation but based on some other kind of reasoning. ${ }^{32}$

28. Encyclopedia Judaica, 5:1067-68.

29. See Aristotle, Physics, I, 1.

30. Aristotle, Topics I, 2.

31. There is some evidence that Maimonides looked down upon dialectical arguments (as at Guide II, 16), but a careful reading of that passage allows for dialectical arguments when a proposition that cannot be demonstrated is accepted as an axiom. Averroes may have equated demonstrative arguments with philosophical arguments and relegated dialectical arguments to religion in Kitab Fasl alMaqal. It has been asserted by Daniel Lasker that most late Medieval Jewish philosophers accepted this Averroistic theory. See D. Lasker, "Averroistic Trends in Jewish-Christian Polemics in the Late Middle Ages," Speculum, 55 (1980): 294-304.

32. "Maimonides, however, tries to show the untenability of the Aristotelian theory of the eternity of the world, or at least its inferiority to the theory of creation, on purely rational grounds. He does not assume a priori that it is contradictory to Scripture" (H. A. Wolfson, "The Platonic, Aristotelian and Stoic Theories of Creation in Hallevi and Maimonides," in Studies in the History of Philosophy and Religion, 2 vols. [Cambridge, Mass.: Harvard University Press, 1973], 21:245). 
Second, it is not entirely clear why "it must be decided" (creation versus eternity). Feldman explains, quite correctly, that miracles imply the ability of God to "interrupt the course of nature." Such an interruption would seem to be inconsistent with eternal necessity. But whether one accepts a certain fact to be a miracle might depend upon one's theory of creation or eternity. As Maimonides sometimes downplays the importance of miracles, why are they so important in this context?

Third, it is true that statements of Maimonides taken out of context imply an appeal to revelation or authority as a source of belief in creation but this must be reconciled with his promise to provide a proof that is close to being a demonstration. He does not oppose a person accepting creation on the basis of revelation; he even recommends it in the Guide. But an appeal to authority cannot be profitably mixed with a quasi-demonstrative argument. ${ }^{33}$ They must be treated as parallel yet separate justifications, each useful for different types of people but logically the latter takes precedence over the former.

Many other commentators misunderstood Maimonides' arguments. Shimon ben Zema Duran, for example, seemed to confuse it with something else. He assumed that Judaism is an axiomatic system like Euclidean geometry and creation a premise from which other beliefs (such as revelation) follow. ${ }^{34}$ This is in keeping with a medieval tendency to seek certain bases for beliefs but not with Maimonides' thinking. Falsifying premises does not refute conclusions inferred from them. 35

33. This analysis supports an esoteric doctrine and/or the position that there is a double truth. In a recent conversation, Daniel Lasker suggested that one can speak of a double truth position only if a Jewish philosopher were to argue that he holds one belief rather than another only because he is Jewish. I use the term "double truth" in a broader sense. What I am suggesting is that for Maimonides, the truth for the masses is whatever authoritative tradition dictates about creation, unless it contradicts reason. But for the Jewish philosopher, quasi-demonstrative argument leads to a somewhat different view of creation.

34. See his Oheb Mishpat, Intro. "It is also known that God's providence necessarily follows from belief in creation," and "It is one of the principles of the Torah to believe in this providence which the Book of Job seeks to verify. Maimonides included it among the great principles, such as belief in God's existence and beliefs similar to it, which are such that there is no hope for him who denies them" (chap. viii). But how does Divine Providence follow logically from creation? The universe could have been created by a malevolent Gnostic spirit.

35. In an excellent analysis of Duran and Maimonides, Menachem Kellner attributes to Duran the belief that resurrection of the dead is logically dependent upon creation and that is why Maimonides did not include the latter as one of the dogmas of Judaism. He then criticizes Duran for not recognizing that if such is the case creation should be the dogma and not resurrection of the dead. Without attempting to interpret what Duran really meant, it seems to me that Kellner is mistaken because believing in creation does not logically obligate one to believe in resurrection. If resurrection is "logically dependent" on creation it must be in a different sense altogether. Perhaps a belief in resurrection (and miracles in general) logically entails a belief in creation (or at least a denial of eternal necessity) 


\section{A. Revelation or Reason?}

As we have seen, some interpret Maimonides' argument for creation to be based on revelation and others say that it is based on reason. How can one be confused about such a fundamental distinction? The reason seems to be that at times Maimonides stresses one and at times the other.

Now inasmuch as this is true in my opinion and inasmuch as this question (I mean to say that of the eternity of the world or its creation in time) becomes an open question, it should in my opinion be accepted without proof because of prophecy, which explains things to which it is not in the power of speculation to accede. For as we shall make clear, prophecy is not set at naught even in the opinion of those who believe in the eternity of the world.

After I have made it clear that what we maintain is possible, I shall begin to make it prevail likewise, by means of speculative proof, over any other affirmations; I refer to my making prevail the assertion of creation in time over the assertion of eternity. I shall make it clear that just as a certain disgrace attaches to us because of the belief in the creation in time, an even greater disgrace attaches to the belief in eternity. ${ }^{36}$

Maimonides creates confusion by saying that in the absence of demonstrative proof one ought to follow prophecy and that it will also be possible to employ rational arguments for creation. Whether one simply follows the authority of prophecy or whether one looks more deeply, however, reason is on the side of creation according to Maimonides. What kind of reason does he refer to?

\section{B. Does Maimonides Employ "Probabilistic" Argumentation?}

Marvin Fox termed Aristotle's favoring of the eternity explanation "probabilistic." While it is not exactly clear where Fox found that term, it was used by Wolfson as well. ${ }^{37}$ Unlike Wolfson, however, Fox asserted that

and the affirmation of eternal necessity would then obligate one logically to deny miracles. This is my opinion and also that of Seymour Feldman. See his article on creation in Encyclopedia Judaica. If that is the case, then Maimonides' omission of creation from his list of dogmas makes perfect sense. See M. Kellner, Dogma in Medieval Jewish Thought (New York: Oxford University Press, 1986), p. 58.

36. Guide II, 16, p. 294.

37. Although Fox does not give citations for his use of the term "probabilistic," the following Arabic phrase in the Guide, II, 15, describing Aristotle's rationale for believing in the eternity thesis is cited by Wolfson as evidence of a "probabilistic" proof: al-dala 'il . . . allati tabdu wa-tamilu al-nafsu ilaiha akthara. See H. A. Wolfson, "The Platonic, Aristotelian and Stoic Theories of Creation in Hallevi and Maimonides," in Studies in the History of Philosophy and Religion, 1:244. Pines translated it as: "the proofs . . . such as occur to the mind and to which the soul inclines." 
Maimonides, unlike Aristotle, could not accept such an argument at all. ${ }^{38}$ He then proceeded to a rather lengthy discussion of probabilistic reasoning. ${ }^{39}$ But those discussions are rather misleading since probability in the modern sense did not emerge until the seventeenth century, and Aristotle was surely not employing it, nor was Maimonides. ${ }^{40}$ Fox seemed to recognize this difficulty and attempted to rescue his opinion by arguing that all probabilistic reasoning, modern, ancient, or medieval, are arguments from analogy. ${ }^{41}$ But that reasoning does not seem valid in this context for two reasons. Probability (of the modern kind) applies to events and not beliefs and the event of interest (beginning of the universe) is utterly unique. ${ }^{42}$

Professor Toledano pointed out that the Pines translation omits the important word akthara (more) which Kafih translated as yoter in Hebrew. Toledano translates it as: "that are apparent and to which the soul (mind) shows greater inclination (inclines more) or is more favorably disposed." This seems to refer to a comparison between two or more theories or explanations, a connotation which is overlooked in both the Pines translation and the Friedlander translation which reads: "proofs . . only apparent and plausible." It should be obvious, however, that these "proofs" have little to do with probability as we use that term today.

38. According to Wolfson, Maimonides disagrees with Aristotle's conclusion and according to Fox he finds the entire method invalid because you cannot deduce origins from current state of affairs.

39. See M. Fox, Interpreting Maimonides (Chicago: University of Chicago Press, 1990), pp. 278-83.

40. "The old medieval probability was a matter of opinion. An opinion was probable if it was approved by ancient authority, or at least was well testified to. This medieval concept of probability is related to our own, but in a surprising way. A new kind of testimony was accepted: the testimony of nature which, like any authority, was to be read." See Ian Hacking, The Emergency of Probability (New York: Cambridge University Press, 1975), p. 43-44.

41. The discussion of analogical reasoning is interesting and reflects the literal meaning of the Arabic text. In the Guide II, 24 the term qi' yas is employed. It means "syllogism," "reasoning," or "analog" (like the Hebrew word "heykesh"), and its most literal meaning according to Professor Toledano is "measuring by fitting one thing against another." But Friedlander mistakenly translated is negation as "improbable and objectionable" (p. 197). The better Pines translation reads "incongruous and dubious." A similar mistranslation is found in II, 23 where Friedlander reads "degree of improbability and deviation from real facts" (p. 195), while the Pines translation reads "how great is their incongruity and what is their disagreement with what exists" (p. 321). What this shows is the very real difference between medieval probability, which meant congruity with how things should be (as in the expression "an improbable marriage"), and modern probability which is linked with numerical frequency distributions.

42. The subjectivistic interpreters of probability might disagree with this statement. For a thorough if somewhat biased account of the efficacy of applying probability to hypotheses, see Karl Popper, The Logic of Scientific Discovery (New York: Harper \& Row, 1965), pp. 254-65. 
Other scholars have also asserted that Maimonides used probabilistic reasoning in his defense of creation. ${ }^{43}$ Furthermore, the term "improbable" does appear in the Friedlander translation in regard to what Maimonides considers invalid proofs for eternity. ${ }^{44}$ Most disturbing to this view, however, is the emerging understanding that medieval "probability" was mostly an appeal to authority. 45 Lenn E. Goodman in his excellent "Maimonides" article in The Oxford Companion to Philosophy states:

Neither biblical creationism or Aristotelian eternalism is demonstrable, it argues. But creation is more probable, and preferable theologically, since it can explain the difference God's act makes in the world and can rely on God's freedom to explain how multiplicity emerges from sheer divine simplicity. 46

Goodman's is on target but "probable" is an unfortunate term.

\section{Maimonides' Arguments and the Kalām}

The Kalām (Mutakallimun) were Muslim religious thinkers who used quasiphilosophical arguments to bolster their beliefs. It is generally thought that Maimonides was more intellectually honest, and he criticized the Kalām severely in the Guide. ${ }^{47}$ But his relationship to the Kalām is not as simple as it appears. Leo Strauss said that the Guide is not a philosophical work at all but a work along the lines of the Kalām. ${ }^{48}$ Seymour Feldman contended that Maimonides accepted the fifth and sixth arguments for creation from

43. Even a great scholar like Wolfson casually remarked that Maimonides employed arguments from probability to prove creation without discussing exactly what kind of probability he might have been using. See H. A. Wolfson, "The Platonic, Aristotelian and Stoic Theories of Creation in Hallevi and Maimonides" in Studies in the History of Philosophy and Religion, 1:236, 244. Wolfson provides the reader with the citations in both the original Arabic as well as the Hebrew translation (see n. 32). He also attempts to connect this medieval probability with Aristotle's concept of probability discussed in Prior Analytics II, 27 (70a3-4). But Aristotle was discussing connections which are usually the case (such as "the envious hate") whereas creation (or eternity) is either always true or never true.

44. Guide II, 23, 24, (pp. 195, 196).

45. This has been well argued by Ian Hacking in The Emergence of Probability. $1995)$.

46. See The Oxford Companion to Philosophy (New York: Oxford University Press,

47. Since the Kalām thought that they had demonstrated creation, and Maimonides rejected that assertion, it is often erroneously thought that he simply accepted it on faith.

48. L. Strauss, "The Literary Character of the Guide for the Perplexed," Essays on Maimonides, An Octocentennial Volume, ed. S. W. Baron (New York: Columbia University press, 1941), pp. 37-91. 
the Kalām. ${ }^{49}$ The sixth argument is a modified version of the fifth, which can be summarized as follows:

Anything imaginable is possible.

Since anything can be different than it is, we need to explain why it is as it is.

Such an explanation involves a principle of particularization which implies a creator.

Therefore, there is a creator and creation.

An examination of this argument will reveal that everything except the purported need to explain why things are as they are is implicit in the first premise, which is the tenth of the twelve propositions of the Kalām. It should be obvious, however, that such a premise is incompatible with "explanation" in any conventional sense because something that explains everything conceivable really explains nothing whatsoever, and the belief that anything imaginable is possible relieves one of the need to explain anything. Therefore, the first and second premises seem inconsistent. But Maimonides explicitly rejects that tenth proposition in his discussion of the Kalām. ${ }^{50}$ It seems odd that he would use an argument based on a false premise (the tenth proposition) even if he were to accept the conclusion regarding creation. Maimonides also attacks this argument for being compatible with the theory of the eternity of the universe as well.51 Despite this, he does in fact call it the "best" argument of the Kalām and employs a modified version of it in Book II, Chapter 1. As it turns out, however, Maimonides can use this argument only by basing it upon a different premise altogether. That premise is that while most events in the universe (at least in the sub-lunar realm) are necessary and determined, some are

49. See S. Feldman, "Abravanel on Maimonides' Critique of the Kalām," in Maimonidean Studies, ed. Arthur Hyman, vols. (New York: Yeshiva University Press, 1990), 1:9-10.

50. See Guide I, 73.

51. He states in the Guide I, 72 that this theory had been adopted by some philosophers who believed in the eternity thesis. It is not difficult to see why because it is really compatible with any explanation whatsoever except one based on laws of causation. A law is always something that can be comprehended in contrast with some more mysterious causal principle. If there is no principle of determinism in the universe itself (operating within time and space), then things must be determined by some eternal non-nomological principle or they must be completely chaotic. The Mutakallimun had argued that the will of God was just such a mysterious principle of determination. Since that "explanation" is unacceptable to most philosophers, they opt for the eternity thesis. But, as Maimonides states, almost all of the "Andalucians" (Jewish philosophers of Spain) attempted to combine a belief in a creating God with immanent causal principles. 
not and that anomalous fact of apparent indeterminacy is incompatible with any explanation other than that of a creator and creation.

\section{LOGICAL ARGUMENTS AND FALSIFICATION}

All rational arguments require premises. An appeal to authority is premised by the belief that an authority is trustworthy and also by some pronouncement of that authority. A dialectical argument in the Aristotelian tradition is premised by at least one statement that is generally agreed upon and perhaps also by some self-evident premise. A demonstrative argument in the Aristotelian tradition is one in which all of the premises are self-evident. What qualifies all of these arguments as deductive is the condition that if the premises are all true, the conclusion must be true as well. But if the premises are false the conclusion may still be true. One can have a perfectly valid argument characterized by false premises and a true conclusion. Disproving a premise (by itself) never disproves the conclusion except where one of the premises may be completely contained within the conclusion, and disproving that premise logically obliges one to reject the conclusion. For example, consider the following argument.

All bachelors in this town are poor.

Jones is a bachelor in this town.

Therefore, Jones is a poor bachelor in this town.

If we reject the minor premise, we must reject the conclusion for reasons that were just mentioned. But rejecting the major premise does not oblige us to reject the conclusion. If we changed the conclusion to: "Jones is poor," rejecting either the minor or major premise (or both) no longer obliges us to reject the conclusion. It is true that in certain kinds of legal reasoning the correct premises are needed in order to make the case. If the evidence was obtained illegally or if the evidence is simply not accepted according to the legally binding burden of proof, the accused person goes free but that does not mean that he or she is not really guilty. This brings us to our main point. In general the only logical way to disprove or falsify a statement is to disprove its logical consequence. 52

52. The technical term for a logically valid argument of this kind is "denying the consequent."

If $\mathrm{p}$, then $\mathrm{q}$

not q

therefore, not $\mathrm{p}$ 
However, it is commonly thought that one can refute or attack a conclusion by subjecting one or more of its premises to doubt. We often hear people say "your conclusions are only as good as your premises." That statement is generally false, but it does point to a very interesting historical fact. The medieval ideal of scientific knowledge was a conclusion that could be demonstratively derived from more or less certain premises. Given that ideal of knowledge (which is no longer our ideal), conclusions are only as good as the premises (assuming that the reasoning is valid). If a conclusion failed to follow logically from certain premises, it would be placed in the category of authoritative (probable) opinion and not in the category of knowledge. A rational argument from authority asserts that since such and such authority asserts $\mathrm{P}$ one should not believe Not $\mathrm{P}$ unless it can be logically demonstrated.53

All beliefs have logical implications and all those logical implications (once they are understood as such) constitute necessary conditions of that belief. This is not always recognized because quite often we mix up those beliefs that are necessary for a certain position and those that are not. For example, in an extremely erudite and well thought out article Arthur Hyman characterizes Maimonides' beliefs regarding creation as follows:

(1) God brought the world into existence after absolute non-existence;

(2) He brought everything into existence through His will and volition (although, as has already been noticed, His wisdom was operative as well);

(3) He brought everything into existence out of nothing; and

(4) Time is created, so that whatever one's theory, creation must be considered as atemporal. 54

Hyman then discusses Maimonides' opinion that the Platonic view of creation out of pre-existing matter does not "undermine the foundations of the Law" and suggests that the Platonic view leaves at least one of those four

The mode of inference is modus tollens and can be contrasted with the fallacious argument called "denying the antecedent."

If $p$, then $q$

notp

therefore, not $\mathrm{q}$

53. Some medieval rationalists might have allowed disagreement with authority on the grounds of near certainty or moral certainty.

54. Arthur Hyman, "Maimonides on Creation and Emanation," Studies in Medieval Philosophy, ed. J. F. Wippel (Vol. 17 of Studies in Philosophy and the History of Philosophy) (Washington D.C.: Catholic University of America Press, 1987), p. 49. 
beliefs intact, namely, (2). This makes perfect sense because of those four beliefs only (2) is a necessary condition for believing in creation. In other words, if (2) turns out to be false (unlike [1], [3], and [4]), creation has been falsified. ${ }^{55}$ Creation by divine will (that is, [2]) is a necessary condition and logical implication of revelation.

What does this tell us about the creation argument? Let us ignore for the moment how we originally arrived at the belief in revelation. Once we believe in it we are obliged to believe in creation because a universe built on either chance or necessity (the alternatives) makes revelation an impossibility.

\section{THE BASIC LOGICAL FORM OF THE ARGUMENT}

Maimonides clearly states that neither eternity nor creation can be strictly demonstrated on the basis of certain premises. But he also states that he can argue for creation in a manner that comes close to being a demonstration. ${ }^{56}$ I interpret this to mean that the argument has the same logical form as a demonstrative argument but that the premises (while not altogether certain) are more certain than any authoritative assertion. ${ }^{57}$ This is quite different from an argument from authority pure and simple. For example, an argument from authority pure and simple would be to cite an opinion of Aristotle or a verse from the Bible, accept it axiomatically and then draw inferences from that. Taking Maimonides at his word that he will give a proof of creation that comes close to being a demonstration and is not simply an argument from authority and given what we have just said about falsification, I will argue that the basic logical form of Mai-

55. (1) is not a necessary condition for creation because "before" and "after" might have no real meaning except in a created universe. (3) is not a necessary condition because even Maimonides admitted the possibility and compatibility with revelation of creation out of pre-existing matter. (4) seems to conflict with (1), but even if they can be reconciled, the nature of time seems to be a philosophial issue essentially unrelated to creation. Those who believe in creation but do not share the Aristotelian/Maimonidean theory of time may be mistaken but are not inconsistent.

56. Guide II, 19, p. 303.

57. Otherwise, such an argument would simply be an argument from authority. An example might be our faith in the medical profession. We trust doctors as authoritative sources of useful information even while knowing that many of their particular opinions are bound to be false. Our trust in medicine in general is based on a kind of reasoning very different from our acceptance of particular medical advice, which we usually take on faith or authority. The belief in an infallible transmission of a revelation makes any such analogy imperfect but one still needs to know when to interpret the revelation literally or allegorically. 
monides' argument against the eternity of the universe and for creation is as follows:

\section{If $\mathrm{P}$, then $\mathrm{Q}$ \\ $\underline{P}$ \\ Therefore, $Q$}

where " $\mathrm{P}$ " is the fact of revelation and "Q" is creation (or the rejection of eternity).

How does one arrive at the premise: If $P$ then $Q$ ? Remember that an eternal universe implies that nothing essentially different (such as revelation) ever occurs. This could be schematized as:

If not $\mathrm{Q}$ then not $\mathrm{P}$

$\underline{\mathrm{P}(\text { not not } \mathrm{P})}$

Therefore, $Q$

or more specifically:

If eternity, then no revelation

But there is revelation

Therefore, no eternity

These are dialectical arguments and, like all such arguments, presuppose a community that agrees on a premise that is not exactly self-evident (revelation). The obvious problem with this argument has nothing to do with its logical form and its premises were generally accepted in the middle ages. Therefore, it comes close to being a demonstration. We might inquire as to whether "If revelation, then creation" is really true. In his own arguments against Aristotle's eternity of the world thesis, Maimonides said that we cannot draw conclusions about the origins of the universe from its present state. While eternity of the universe seems to be inconsistent with revelation (in the current state of things), how do we know that an eternal universe could not have evolved to a point where revelation is possible?58 This may require revising the argument.

58. Is eternity consistent with a universe that evolves under the tutelage of God? Though eternity implies no essential change, unusual events could occur occasionally but recurrently (perhaps every 10,000 years). From our perspective such events would appear unique. According to Joseph A Buijs, Maimonides states that eternity is not really inconsistent with "divine purpose and will" and cites the Guide II, 19, 22 as proof. I am unable to find that assertion. What Maimonides does say at the end of II, 19 is that some commentators have made that assertion. In practically all other matters I agree with Buijs who states: "What is actually at issue in this dispute is which view is compatible with a belief in divine purpose and will." See J. A. Buijs, "The Philosophical Character of Maimonides' Guide," in Maimonides: A Collection of Essays, ed.J.A. Buijs (Notre Dame, Ind.: Univ. of Notre Dame Press, 1988), p. 62. 


\section{THE RATIONAL STATUS OF BELIEFS}

There are many beliefs that we hold that cannot be rationally justified. Some of those beliefs are held quite fervently. Religious and political beliefs and beliefs about loved ones are obvious examples; some would also say that many, and perhaps all, scientific hypotheses cannot really be rationally justified either. Yet there is a major difference between a person who holds rationally unjustified beliefs that he/she would never abandon under any circumstances and one who would be willing to abandon his/her beliefs if reason so demands. While such a compromise between rationally unjustified beliefs and reason may be a good description of our normal state of affairs, it is not clear whether it can be normatively justified if reason is our only norm. But it would be difficult to find the human being for whom reason $i s$ the only norm and some even argue that reason provides no ends at all but only means. This, however, was not the position of either Maimonides or the many medieval rationalists who believed that reason provided ends and means.

In an article filled with extremely interesting suggestions, Charles Manekin asserts that Maimonides in the Guide shows little interest in knowledge (rationally justified belief) but much interest in belief in general. ${ }^{9}$ Perhaps that was somewhat of an overstatement, but it certainly was the case regarding creation/eternity and to a certain extent regarding cosmological questions in general. This brings us to how he viewed scientific beliefs.

\section{MAIMONIDES’ UNDERSTANDING OF SCIENTIFIC TRUTH}

Maimonides alludes to the fact that some scientific theories (Aristotelian physics, for example) are rationally demonstrable and others (astronomy) are not. ${ }^{60}$ In this, he seems to have departed from a strict Aristotelian view of science.

Aristotle states that science (knowledge) is "understanding a thing by means of its causes." ${ }^{1}$ By cause, however, Aristotle means efficient, material, formal, and final causes, but only the first of those is recognized as a cause

59. C. H. Manekin, "Belief, Certainty and Divine Attributes in the Guide," in Maimonidean Studies I:117-41.

60. He refers to scientific theories of Aristotle as "guesses" or "conjectures" (see Guide II, 22). But his extreme confidence in Aristotelian physics brands that system as certain knowledge.

61. Aristotle, Metaphysics, 1013-1014a. 
by modern science. Knowledge, according to Aristotle, is acquired by demonstration with the exception of knowledge of primary premises, which is independent of demonstration. ${ }^{2}$ According to Aristotle, beliefs about particulars or accidents is not science or knowledge at all but opinion. ${ }^{63}$ For Aristotle science is the study of the unchanging essences of things and such knowledge is to be acquired through demonstrative arguments and primary premises (self-evidently true by a faculty of intuition). ${ }^{64}$

Modern science, on the other hand, deals with particulars even though it strives for theoretical simplicity and comprehensibility. This has presented a problem for modern philosophy of science, which on the one hand has rejected Aristotelian essences but on the other hand has not wanted to admit that all theoretical knowledge is merely statistical or probabilistic as is the prediction of particular events. Philosophers of science might either argue that scientific theories are justified by inductive reasoning or are simply our best current conjectures which have so far eluded falsification. Considering the nature of medieval science, I would suspect that for Maimonides any scientific theory that was not demonstrable would be conjectural and this, in fact, is what he says:

\begin{abstract}
Everything that Aristotle has said about all that exists from beneath the sphere of the moon to the center of the earth is indubitably correct, and no one will deviate from it unless he does not understand it or unless he has preconceived opinions that he wishes to defend or that lead him to a denial of a thing that is manifest. On the other hand, everything that Aristotle expounds with regard to the sphere of the moon and that which is above it is, except for certain things, something analogous to guessing and conjecturing. All the more does this apply to what he says about the order of the intellects and to some of the opinions regarding the divine that he believes; for the latter contain grave incongruities and perversities that manifestly and clearly appear as such to all the nations, that propagate evil, and that he cannot demonstrate. 65
\end{abstract}

Given the Aristotelian ideal of demonstrative knowledge that was operating in an age of faith, any mere conjecture (scientific or philosophical) was no match for a strongly held religious belief. That is why Maimonides' main task is to convince his reader that Aristotle not only did not demonstrate the eternity of the universe, but that he did not even think he had. It is easy to misunderstand Maimonides as a proto-empiricist—and perhaps for good

62. Aristotle, Posterior Analytics, 72b18-20.

63. Aristotle, Posterior Analytics, 74b; Metaphysics 1026b1-5.

64. For Aristotle, intuition is connected to the process of induction, by which he means that the same or similar essence is intuited in a variety of objects or events. For example, by encountering a multitude of humans we induce that all have rational souls.

65. Guide II, 22, pp. 319-20. 
reason. 66 If there are elements in his thought that seem modern and empirical, we should still not forget that for him the two major justifications for belief were reason and revelation. Whenever the literal meaning of a sacred text can be demonstrated to be false it must be reinterpreted. Scientific truth as the result of the empirical investigation of nature would rank far beneath reason and revelation and was still in its infancy, so we can eliminate empirical criteria as the mode of decision making for Maimonides in the creation/eternity dispute. Did he accept creation solely on the basis of prophecy? His insistence on rational arguments indicates that belief in creation is so fundamental that it cannot be based on revelation alone.

\section{ARGUMENTS FOR CREATION IN THE GUIDE}

I have shown the effective bare bones logical argument that Maimonides might have employed if his argument were to come close to being a demonstration. As we will see, it requires supplementation with other premises if we are to look upon it at all favorably; however, the basic form of the argument will remain the same. We cannot infer that this is his argument by carefully reading the text. But the arguments that he does explicitly cite are not convincing. So either he believes in unconvincing arguments, does not really believe that there are arguments for creation, or believes that we must look for another argument. I opt for the third option. Interestingly, despite its rather obvious nature, many commentators have mistaken it for very different kinds of arguments. The reason for that is not hard to discern. Maimonides employs many logically ineffective arguments in the Guide which can only be understood as rhetorical. I will briefly review those ineffective arguments and show that they have no logical power. We can assume that Maimonides was also aware of this.

\section{Book II, Chapter 13}

Here Maimonides notes that there are three opinions regarding creation among those who believe in a deity. The first is the opinion of the Law of Moses (creation ex nihilo). The second opinion is that of the Platonic philosophers who argue that it is absurd for something composed of form and matter to come into existence out of nothing and to ascribe such power

66. The dismissal of Aristotelian science as conjecture was considered radical even in the sixteenth century. See Francisco Sanchez, That Nothing is Known, ed. E. Limbrick and D. F. S. Thomson (Cambridge: Cambridge University Press, 1988), p. 172 n.19. 
to God is like believing that He can make $2+2=5$. Instead, they argue for creation out of a pre-existing matter. The third opinion is that of the Aristotelians who believe that God and the universe are co-eternal. He mentions the Epicureans who supposedly believed that there is no God and that everything comes about by chance but sees no purpose in discussing that opinion since the existence of God has been "demonstrated" which is to say that it is a logical certainty. There is also no sense in arguing with the Platonists because from the point of view of the Law of Moses it makes little difference whether the universe is eternal or only the matter from which it comes. ${ }^{67}$ He promises to show how creation ex nihilo is not only possible but that to believe in it is an obligation. ${ }^{68} \mathrm{He}$ also promises to explain Aristotle's "proofs" for the eternity of the universe.

\section{Book II, Chapter 14}

There is no point in refuting any of the philosophers besides Aristotle regarding their disagreements with the "fundamental principles of the Law." Since Aristotle's arguments are the most powerful, refuting him will serve to refute the others as well. He mentions four arguments of Aristotle (which, presumably, will be refuted later on):

(1) Aristotle argues that motion in the absolute sense is not subject to creation or destruction because every motion is produced by some other motion. Indeed, for Aristotle, time is dependent upon motion and, therefore, time is not subject to creation or destruction either.

(2) Prime matter, which admits no form, is not subject to creation or destruction. Since it has no form, it is not generated because to create or generate something means to endow it with form.

(3) When a thing passes away it is due to something "contrary." But the circular motion of the heavenly bodies has no contrary and, therefore, is not subject to destruction. That which is not subject to destruction is not subject to creation either.

(4) With everything produced in time, its possibility precedes its creation. Imagine a time prior to the creation of the world. Either its creation is necessary, possible, or impossible. If it is necessary, it can't lack existence and is eternal. If it is impossible, it cannot exist. If it is possible, there must be a substrate (matter) for its possibility. Hence, either the world is eternal or it does not exist at all. An intelligent Mutakallimun responded to this argument by asserting that the prior

67. Belief in creation out of pre-existing matter is not completely foreign to Jewish thought and does not falsify revelation as Aristotle's view does. This seems to be an argument from authority.

68. This is consistent with his method. First you show that the mandated belief is not impossible, then you show that it is obligatory and finally you show that it is rationally defensible. 
possibility resides in the creator and not in the object of creation. Maimonides sees no difference between these states; to ascribe possibility to the creator is equally problematic.

Maimonides mentions some arguments for eternity by later followers of Aristotle. They resemble the previous arguments but in a more theistic mode, ascribing imperfection to a deity who acts at times and not at other times. Finally he mentions a different argument. Since all of the nations believed in an eternal universe, that belief must be natural and not conventional. 69

\section{Book II, Chapter 15}

In this chapter, Maimonides proposed to show not only that Aristotle failed to demonstrate his eternity thesis but never even thought that he had. Aristotle attempts to corroborate his view by referring to the physicists of the past, but arguments from authority do not mix well with demonstrative arguments-who would have known this better than Aristotle? In a similar vein, Aristotle insists on airing the opposing views prior to promulgating his own and justified it by asserting that this will make his own views more acceptable. But if a matter is demonstrated, as is true of mathematical/logical truths, it does not matter what other views precede it. Certainly, Aristotle knew the difference between demonstrative arguments and rhetorical or dialectical ones. Therefore, he could not have believed that the eternity of the universe was demonstrated.

\section{Book II, Chapter 16}

This short chapter is one of the most difficult of the entire book as it seems inconsistent with oft-repeated opinions of Maimonides and may be internally inconsistent as well. Yet it may hold the key to his method. Here Maimonides promises to explain his own beliefs regarding creation; it is not impossible, he asserts, and any argument to the contrary can be invalidated. Creation versus eternity, he asserts, is an "open question." If a proposition cannot be demonstrated it is best to leave it unresolved rather than to "prove" it by dialectical methods. Creation ex nihilo should, therefore, be accepted solely on the basis of prophecy, which is even consistent with the

69. That argument seems to rest on an Aristotelian notion of an essential human nature which somehow includes goodness and truth. But this should not be surprising since Maimonides has already stated that only Aristotle's arguments are worth refuting. 
eternity thesis. ${ }^{70}$ But he promises that once he proves its possibility he will "make it prevail" on the basis of a non-demonstrative argumentation. ${ }^{71} \mathrm{He}$ admits that a "certain disgrace" attaches to his view and to those who believe in the eternity of the universe but the disgrace of the latter is greater. ${ }^{72}$

\section{Book II, Chapter 17}

Maimonides now explains why the eternity of the universe is such a plausible view but why it is hardly proven. A story is told of a boy shipwrecked upon an island who grows up never having any experience with women because his mother had died when he was a few months old. He asks a man (perhaps his father) how people come into existence. He is told about women and pregnancy, and so on. For him, with his limited knowledge of human life, the idea of intrauterine life is fantastic and unbelievable. He believes that he can disprove this theory of human origins based on the nature of human life as he knows it. Similarly, Aristotle and his followers cannot conceive of an absolute beginning of the universe, based upon the world as they know it. This parable shows that one cannot argue about origins based on the present state of affairs.

70. This seems contrary to what he asserted previously about the inconsistency between revelation and eternity. Professor Toledano interprets it as meaning that since Aristotle did not prove the eternity thesis, it cannot be used as a basis for refuting prophecy. We could imagine a person who believes in two inconsistent theories: the eternity thesis and prophecy and has no rational way of resolving the conflict. Maimonides asserts that in such a case one should follow prophecy.

71. This seems inconsistent with his prior condemnation of dialectical arguments but it can be explained. First one should accept a proposition as an axiom based on authority always recognizing that it could be false and has not been proved. If one finds no good reason to reject it, one can then attempt to prove it by non-demonstrative means. But if one first attempts the proof and accepts it, as the Kalām did, then no evidence to the contrary is likely to change one's mind.

72. But the term "disgrace," while correct literally, may not be the best translation of the Arabic term shana "at (ugliness, repulsiveness, hideousness, disgrace) and what we may be dealing with here is degrees of incongruity. Kafih translates the term into Hebrew as "difficulties, objections." In other words, the argument for creation involves one in undesirable consequences. Ibn Tibbon translates it there as "absurdity." In other places the same word is translated as "strangeness" by Kafih and as "incongruity" by Pines. Perhaps Pines avoided that translation here because it would create an additional problem. What Maimonides would then have been saying is that the argument for creation is not only speculative but also incurs difficulties, strange conclusions, or incongruities. This interpretation would lead to the following conclusion. The question of creation versus eternity is not only an "open question" in terms of deciding between the two but even after one decides, it becomes obvious from the incongruities produced that one's understanding of it is essentially inadequate. This would most likely stem from the fifth cause of inconsistencies. 


\section{Book II, Chapter 18}

In this chapter, Maimonides attempts to refute certain views about creation which make it seem to be an impossibility. Could the deity pass from potentiality to actuality by acting at a certain time? As an immaterial being is never in potentiality, that argument is refuted. It was argued by some that eternity is necessary because there are no incentives for God to act or change. Maimonides considers this to be a subtle matter. The essence of a being may remain the same but supervening accidents induce him or her to act. Another argument is that God's wisdom is eternal and unchanging and whatever necessarily proceeds from it is likewise eternal. This is a feeble argument because we are so ignorant of God's wisdom and providence. Finally, he discusses Aristotle's remark that the nations all agreed that God and the angels are in heaven. Maimonides agrees that the heavens supply proof of the existence of God and the angelic intellects but no proof of the eternity of the universe.

\section{Book II, Chapter 19}

This is the chapter that seems to have confused many commentators because Maimonides proposes to prove creation in a manner that comes "close to being a demonstration." He warns the reader that his proofs may resemble those of the Mutakallimun (particularly regarding particularization) but they will not really be the same at all. For the Kalām, particularization (takhsis) follows from the basic view of atomism and from the tenth proposition, but Maimonides promises to show particularization from "the nature of that which exists." His argument is long and tedious; he quotes Aristotle regarding the fallibility of this science and also remarks on certain astronomical anomalies. The gist of the argument can be summarized in his own words. "If the matter of the spheres is one and the same, in virtue of what thing has any sphere been so particularized as to receive a nature other than the nature of any other sphere? ... There must of necessity be something that particularizes." 73 We can see that this argument is different from the Kalām argument. According to the Kalām, everything is composed of atoms that lack properties, and the qualitative aspect of reality is a constant free creation of God. But for Maimonides, that is not the case regarding sub-lunar reality. ${ }^{74} \mathrm{He}$ admits that this argument might be com-

73. Guide II, 19, pp. 311-12. An interesting part of this argument is that it seems to rest on an Aristotelian world-view regarding a common material substrate and assumes the need to explain unusual aspects of reality. But the fact that something functions as an explanans does not guarantee its reality. Many explanatory devises are abstracta (unreal theoretical entities).

74. As Shlomo Pines points out in his excellent discussion of particularization and the Kalām in his introduction to the Guide (pp. cxxiv-cxxxi), this is open to two 
patible with a theory of eternal creation and promises to discuss this more fully.

\section{Book II, Chapter 20}

Here Maimonides attempts to use Aristotle's own argument against chance occurrence to buttress the argument for creation. Chance occurrences do not ordinarily appear all the time or even in the majority of cases, but we do find them in many natural occurrences. Therefore, spontaneity cannot be invoked as an explanatory principle, according to Aristotle, who believed that each thing has a cause that necessitates its existence and is connected with its essence. But for Maimonides, one cannot logically combine a belief in necessity with a belief in creation from purpose as they are "near to a combination of two contraries." In other words, they cannot both be true. 75 Later philosophers, however, either thought that purpose and particularization can be combined with the eternity of the world or they misunderstood Aristotle to be referring to purposeful creation. Maimonides promises to treat those thinkers more fully in the ensuing chapters.

\section{Book II, Chapter 21}

Here Maimonides attempts to show that those who attempted to combine the Aristotelian concept of an eternal universe with a creator God are mistaken. His arguments are basically the same as his argument against necessity and eternity of the universe. He concludes as follows:

Accordingly the matter is reduced to this, and the discussion finally leads us to an inquiry concerning the diversity existing in the heavens, with regard to which it has been demonstrated that it must necessarily have a cause. The inquiry concerns the question whether this cause is the ground of this diversity, the latter having necessarily proceeded from the existence of this cause, or whether this cause is the agent that has brought about this diversity and has particularized it in the way in which we, the followers of Moses our Master, believe. . . . Thereupon I shall begin to explain to you, with the help of speculation and philo-

interpretations. According to one, the spheres are qualitatively the same and according to the other (Averroes's view), human reason is incapable of cognizing what differentiates (particularizes) them. The latter view would seem to imply some immanent principle of causality and differentiation which was denied by Avicenna and al-Ghazali in keeping with the Moslem predisposition for transcendental explanations. In the thought of al-Ghazali, for example, everything is particularized by God, but for Avicenna it is the work of the First Intelligence that emanates from God.

75. Please note, however, that Maimonides does not claim that these positions are contradictory. They cannot both be true but they can both be false. 
sophic proofs devoid of falsification, my preference in favor of the opinion according to which the world has been produced in time. ${ }^{76}$

\section{Book II, Chapter 22}

Maimonides expresses doubts about certain aspects of Aristotelian science and metaphysics. If only a simple thing can issue from a simple thing, how do we ever get to complexity? He repeats some doubts previously expressed regarding the movements of the heavenly bodies. He introduces doubts about the applicability of the conventional form-matter dichotomy to the heavenly bodies. All these perplexities can be resolved, he says, by reference to a Creator.

Maimonides also says some interesting things here about science in general. In keeping with the presuppositions of Aristotelian science he admits that everything that Aristotle said about sub-lunar reality is not only correct but "indubitably correct." No one would oppose it unless they failed to understand it. This is in keeping with the Aristotelian ideal of science as necessary truth. But when it come to the heavens, Aristotle's views are mere "guessing and conjecturing." Presumably, he might also have said the same about the Ptolemaic astronomy of his own day.

He asks not to be criticized for introducing doubts about Aristotle and admits that doubts can neither disprove a theory nor prove a contrary one. He introduces a method that some have likened to probability or induction. Alexander of Aphrodisias said that when demonstrative arguments are not available, one should choose the opinion that engenders the least number of doubts. Maimonides asserts that he has already used this method though it was never explicitly stated.

We have acted in this way when it was to our mind established as true that, regarding the question whether the heavens are generates or eternal, neither of the two contrary opinions could be demonstrated. For we have explained the doubts attaching to each of the opinions and have shown to you that the opinion favoring the eternity of the world is the one that raises more doubts and is more harmful for the belief that ought to be held with regard to the deity. And this, in addition to the fact that the world's being produced in time is the opinion of Abraham our Father and our prophet Moses, may peace be on both of them. ${ }^{77}$

76. Guide II, 21, pp. 315-16.

77. Guide II, 22, p. 320. It is not clear whether he refers to doubts about the opinion in question or doubts about other religious dogmas. Please note the reinterpretation of the term "doubt" to include not only what might ordinarily be considered rational doubt but also to include doubts about religious dogma. In other words, Alexander had been referring to doubts about an explanatory hypothesis, not doubts engendered by religious dogma. But as we shall see, it is precisely this latter type of argument that Maimonides really relies upon. 
Admittedly, there is some ambiguity here, but it certainly seems that this method of doubt supplements another argument from authority, and he clearly attempts to differentiate the two. Presumably, his method of doubt works even for one who does not accept the authority of Abraham and Moses. Maimonides now promises to pursue this method of comparing doubts.

\section{Book II, Chapter 23}

In this chapter Maimonides appears to pursue an inductive approach to the matter under discussion but it is really more of a normative one. He begins by revising Alexander of Aphrodias's method of appraising theories by comparing doubts. It is not the number of doubts that is significant but "how great is their incongruity and what is their disagreement with what exists. Sometimes a single doubt is more powerful than a thousand other doubts"78 Now Maimonides introduces a condition which makes this method practically impossible to apply and he seems to contradict himself as well:

Furthermore this comparison can be correctly made only by someone for whom the two contraries are equal. But whoever prefers one of the two opinions because of his upbringing or for some advantage, is blind to the truth. While one who entertains an unfounded predilection cannot make himself oppose a matter susceptible to demonstration, in matters like those under discussion such an opposition is often possible. Sometimes, if you wish it, you can rid yourself of an unfounded predilection, free yourself of what is habitual, rely solely on speculation, and prefer the opinion that you ought to prefer. However, to do this you must fulfill several conditions. The first of them is that you should know how good your mind is and that your inborn disposition is sound. This becomes clear to you through training in all the mathematical sciences and through grasp of the rules of logic. The second condition is to have knowledge of the natural sciences and to apprehend their truth so that you should know your doubts in their true reality. The third condition concerns your morals. For whenever a man finds himself inclining - and to our mind it makes no difference if this happens because of his natural disposition or because of an acquired characteristic - toward lusts and pleasures or preferring anger and fury, giving the upper hand to his irascible faculty and letting go its reins, he shall be at fault and stumble wherever he goes. For he shall seek opinions that will help him in that toward which his nature inclines. I have drawn your attention to this in order that you should not be deceived. For someone may some day lead you into vain imaginings through setting forth a doubt concerning the creation of the world in time, and you may be very quick to let yourself be deceived. For in this opinion is

78. Guide II, 23, p. 321. 
contained the destruction of the foundation of the Law and a presumptuous assertion with regard to the deity. ${ }^{79}$

It should be apparent that few, if any, religious believers can be truly indifferent between an opinion which confirms their faith and one which is inconsistent with it. Maimonides is concerned about people being led astray by their moral weaknesses-and so he should as a moralist. But as a philosopher, in consonance with what he has himself stated, he should also be concerned about a person being led away from the truth by loyalty or irrational attachment to religious dogma yet he does not seem so concerned about the latter. ${ }^{80}$ In fact, he abandons the method of comparing doubts altogether when he warns: "Do not turn away from the opinion according to which the world is new, except because of a demonstration." 81 Maimonides now clearly recognizes that he has gone beyond a rational critique of Aristotelian arguments and asks the reader not to criticize him for engaging in rhetoric because Aristotle also engaged in rhetoric to support his opinion. Quoting the Talmud, he argues:

In such cases it may truly be said: Shall not our perfect Torah be [worth as much] as their frivolous talk? If he ${ }^{82}$ refers in support of his opinion to the ravings of the Sabians, how can we but refer in support of our opinion to the words of Moses and Abraham and to everything that follows therefrom? 83

\section{Book II, Chapter 24}

The point of this chapter is to reiterate that Aristotle's astronomy is faulty and not as good as Ptolemaic astronomy but his physics is "in accordance with reasoning." But this is not surprising since: "The heavens are the heavens of the Lord, but the earth hath he given to the sons of man."84 The end result: skepticism regarding things far away which are alleviated by blind faith.

And to fatigue the minds with notions that cannot be grasped by them and for the grasp of which they have no instrument, is a defect in one's inborn disposition or some sort of temptation. Let us then stop at a point that is within our capacity, and let us give over the things that cannot be grasped by reasoning to him who was reached by the mighty divine

79. Guide II, 24 and 23, p. 321.

80. It is problems like this that may have led Leo Strauss to assert that the Guide is not a philosophical work at all but in the very Kalām tradition which Maimonides purported to oppose. I am not completely in agreement with that position and in fact in other contexts Maimonides admits that sacred texts can lead people away from the truth. See Guide I, 31.

81. Guide II, 23, p. 322.

82. He refers to Aristotle here.

83. Guide II, 23, p. 322.

84. Psalm 115:16. 
overflow so that it could be fittingly said of him: With him do I speak mouth to mouth. That is the end of what I have to say about this question. ${ }^{85}$

\section{Book II, Chapter 25}

It is in this chapter that Maimonides gives his real seasons for rejecting the eternity of the world and for adhering to the doctrine of creation. It is not because of the literal meaning of the Torah. Though the Bible is authoritative, it can always be interpreted allegorically when it conflicts with reason as when it refers to God as being corporeal. There are two reasons for his decision. First, eternity has not been demonstrated, nor has creation been disproved by demonstration. Second, unlike the belief in the incorporeality of God, belief in eternity of the universe really undermines the Torah. This is a subtle distinction. He admits that in the minds of the ignorant anything that goes against its literal meaning undermines the Torah but the eternity thesis undermines it in a more fundamental way. It undermines the very possibility of revelation.

\section{AN EXPANDED SCHEMATIZATION OF MAIMONIDES' ARGUMENT}

We have seen that the basic argument, while logically valid, can be attacked in terms of its premises. Hence, an expanded argument is needed such as the following that would work equally well for either creation ex nihilo or a Platonic creation out of pre-existing matter:

If revelation is a fact, God did something quite novel in the world; this is consistent with creation but inconsistent with an eternal universe where nothing essentially novel occurs.

Aside from creation and eternity there are no other tenable explanations for the existence of the universe.

We, heretofore, have believed in revelation as a fact as well as its teaching regarding creation.

The eternity of the universe has not been logically proved nor has creation been disproved.

Therefore, we have no reason to revise our belief in revelation and creation and the Aristotelian theory of the eternity of the universe is rejected. 86

85. Guide II, 24, p. 327.

86. It should be noted that the "Aristotle" who was applauded or attacked by medieval scholars was usually a Neoplatonized Aristotle as seen through the eyes of Avicenna or al Farabi. 
This is a much more complex argument than the original one. It revolves around Maimonides' prescription to first accept creation on authority and then try to prove/disprove it (if you cannot disprove a perfectly useful belief, continue to believe it). Revelation as a fact no longer implies creation but is merely consistent with it and inconsistent with eternity. Maimonides' argument could be attacked because premises two and three seem arbitrary but they give him additional options. He can argue that his support for creation is not dependent upon a literal reading of the Torah because disregarding the content altogether the mere fact of revelation implies creation as an explanation (as long as there are no other tenable alternatives). And if there turns out to be a tenable alternative, he could fall back upon the content of revelation which, indeed, teaches that God created the universe. 87 The argument is in the mode of conjecturing solutions to problems where the answers cannot be logically demonstrated and then testing their logical consequences. As long as the logical consequences of a useful theory are not shown to be false, the theory stands; how one arrived at it is irrelevant. The belief in revelation has been a useful one and it entails rejection of Aristotle's eternity thesis. We have no other compelling reason to accept the Aristotelian thesis and there are no other viable options, so we retain our belief in creation.

What is the status of this argument? It does not disprove the eternity thesis. Even if we could disprove eternity, it does not prove that revelation (or creation) is a fact but rests on the fact of revelation. That is not to say that if revelation were disproved creation would be impossible but the argument is only logically valid if one accepts revelation. What he is saying in the Guide can be paraphrased as follows. I give many persuasive but non-demonstrative arguments in favor of creation and opposed to eternity. But if one believes in revelation one is obliged by logic to reject eternity and believe in creation unless creation demonstrated to be false.

\section{CONSONANCE WITH MAIMONIDES' OTHER WRITINGS}

We discussed Maimonides' concept of "foundation of the Torah." Although it refers to an important ingredient, it is not a dogma that is essential to the practice of Judaism. ${ }^{88}$

87. Can one really differentiate between the content of revelation and the fact of revelation? Perhaps to the believer revelation is utterly unique and can't be included in any general conceptual scheme. This was noted by Karl Jaspers in Philosophical Faith and Revelation (New York: Harper Row, 1967). That seems to be a psychological tendency and explains the intolerance of religions based on a claimed revelation. Each one insists on only one authoritative revelation.

88. The Arabic word is qawā 'id al sharī 'a, which Kafih translates into Hebrew as yesodot ha torah. According to Professor Toledano it means "groundworks, 
Belief in creation was not among Maimonides' original thirteen essential principles or dogmas of Judaism listed in the commentary on Helek. Late in his life, after he wrote the Guide, he does seem to have included creation as a part of the fourth principle. ${ }^{89}$ Many explanations have been adduced for this but there is one which is consistent with our interpretation. With any theory or model one must distinguish between beliefs which constitute the essential body of that model and those which are logical inferences. One must believe the former in order to truly accept the model but the latter must only be accepted once their logical inference from the theory has been established. Prior to the groundbreaking work of Maimonides, creation and eternity were irrelevant to the essence of Judaism since Genesis can be interpreted allegorically. But once it was established that belief in eternity destroys the Law things change radically. Convinced that his argument for creation in the Guide was logically valid and seeing the danger of the eternity thesis, Maimonides took it upon himself to redefine Judaism. ${ }^{90}$ This may not be the only time that he did so but in this case he seems to have redefined his own initial definition. ${ }^{91}$

\section{SUMMARY}

Maimonides gives three types of arguments for creation and against eternity of the universe:
(A) Arguments from authority
(B) Quasi-empirical argument
(C) Argument from consistency of belief

The argument from authority becomes superfluous once the effective argument is understood. The quasi-empirical arguments are inconsistent with his views and inconclusive at best. All that remains is an argument from

foundations, fundaments, bases." In referring to the fundamentals of the Torah Maimonides uses either the terms qawa 'id (singular qa ida) or asl. They refer to a broad range of fundamental beliefs and are not restricted to the thirteen principles or dogmas enunciated in Perek Helek.

89. The manuscript is to be found in Oxford University Library (MS Pococke 295; Neubauer no. 301). Its authenticity has been disputed, but it was published by Solomon Sassoon in his Maimonides Commentarius in Mischam (Copenhagen: Ejnar Munksgaan 1961), ii, plate 301. Its authenticity was attested to by Rabbi Sassoon, Rabbi Kafih, and Shlomo Pines. Isaac Sassoon, the son of Solomon Sassoon, in a recent conversation stated that he is still convinced of its authenticity.

90. I am not referring to the Guide but to the just cited revision of his thirteen principles.

91. For an excellent discussion see Kellner, Dogma in Medieval Jewish Thought. 
consistency of belief. Eternity, inconsistent with the concept of revelation, is therefore rejected. While eternity is rejected and creation accepted, the kind of creation accepted is an esoteric one which has little to do with the literal meaning of the Biblical text. The argument is rational but the premises are neither self-evident nor rationally justified.

\section{CONCLUSION}

What I have described as Maimonides' argument may seem an unusual explanation of the writings of a twelfth-century dogmatist. ${ }^{92}$ My assumptions are that he was well acquainted and enamored with logic, held strongly to most traditional beliefs, but had esoteric views as well.

There is something disturbing about the argument. It proceeds from belief to belief, not from facts to belief, and it appears subjective. If revelation were a generally agreed upon belief (as in the Middle Ages) and no alternatives to creation and eternity were plausible, then his argument would indeed come close to being demonstrative. Revelation, however, is no longer conventional wisdom but the object of specific religious faiths and his argument may not mean much to those who do not already believe in it. The argument, however, can be shared by a number of religious communities and Maimonides acknowledged that belief in creation was shared by Judaism, Christianity, and Islam despite their differences on many other issues. ${ }^{93}$

Maimonides argued against essential knowledge of God. Likewise, modern science, which reveals much about matter, leaves us perplexed regarding its essential nature. As we become less certain regarding the nature of physical reality, conflict between science and religion moves to the human reality. As Thomas Aquinas states: "For errors about creatures sometimes lead one astray from the truth of faith, so far as the errors are inconsistent with true knowledge of God." 94 Materialism in regard to human nature, for example, conflicts with religion and leads to moral relativism. Like the eternity thesis, it "destroys the Law in its principle, necessarily

92. This is not meant in a pejorative sense but as a description of a person who pioneered the formulation of dogma in Judaism. See Kellner, Dogma in Medieval Jewish Thought.

93. The kind of creator, like the kind of creation that is believed in by the three monotheistic faiths, requires a belief in revelation. Unlike some creation myths, the Biblical God is the Lord of nature and creator of matter who cares about humankind and expresses that caring by an act of revelation. As Burrell states: "Affirming creation required faith in a revelation, and revelation presupposed one revealing." See D. B. Burrell, Aquinas' Debt to Maimonides, A Straight Path: Studies in Medieval Philosophy and Culture: Essays in Honor of Arthur Hyman, ed. Ruth Link-Salinger (Washington, D.C.: Catholic University of America Press, 1988), p. 41.

94. Thomas Aquinas, Summa Contra Gentiles Book Two: Creation, trans. J. F. Anderson (Notre Dame: Ind. Notre Dame Press, 1975), p. 32. 
gives lie to every miracle, and reduces to inanity all the hopes and threats that the Law has held out."

It is a mistake to think that deep metaphysical questions like creation versus eternity are irrelevant to practical human life and Maimonides was very much aware of that. The notion that humankind was created in the image of God, for example, must have had a tremendous impact upon the self-image of the Western peoples. Inevitably, however, thinking people want to understand what is meant by "image" and "create." A modern reconstruction of Maimonides' argument might assert that revelation and its attendant creation doctrine is essential to the perfecting of the human virtues (including intellectual virtue). 95 That assertion, if it is to be a significant one, however, would imply a prior concept of human nature and virtue. ${ }^{96}$ "The Torah speaks in the language of man," and knowledge of human nature distinguishes the universal language of man from the historical language of particular men. 97 Our view of humanity has changed from Biblical times but two things have remained constant. We believe in free will in our practical reasoning and as Adam was given the power to name all creatures (Genesis 2:18), we also name and conceptualize all things. ${ }^{98}$ But knowledge of those "things" may never be true knowledge as long as man remains a mystery to himself.

95. In the Guide III, 54, Maimonides lists four human perfections. The first two (possessions and bodily perfection) do not require it. The other two (moral and intellectual virtue) do. Without creation/revelation, free will and moral virtue are impossible. Without moral virtue, intellectual virtue is impossible. For a good discussion see A. Altmann, "Maimonides' Four Perfections," in A. Altmann, Essays in Jewish Intellectual History (Hanover, N.H: Brandeis University Press, 1981), pp. 65-76.

96. Otherwise, revelation simply defines human virtue and the claim is tautological.

97. Man is created by God with a nature but the only way to fully appreciate it is through revelation. Conversely, any attempt to understand revelation without some knowledge of the human essence is doomed to failure. Religion and philosophy each supply something unique. The Aristotelian nature/virtue and the Biblical commandments reinforce one another.

98. Maimonides interprets Adam's power to name creatures as meaning that language is conventional and not natural (Guide II, 30). That debate regarding the nature of language goes on. But if revelation is to be everlastingly true, it must be addressed to the very essence of humanity, and freedom constitutes a part of that essence. David Burrell describes human freedom following "as a perfection utterly consonant with the existential order of a universe conceived as the gift of a free creator." See D. Burrell, "Creation and 'Actualism'," Medieval Philosophy and Theology 4 (1994): 33. Maimonides may not have held such an expansive view of human freedom but there is no reason why his argument could not lead to something that he himself could not have envisaged. The rejection of idolatry may also be a necessary precondition for an adequate conception of human nature/virtue. For Maimonides, the purpose of the Mosaic Law is the destruction of idolatry. Leo Strauss opined that the rejection of idolatry does not really follow strictly from monotheism and divine incorporeality but only from the doctrine of creation $e x$ nihilo. See his introductory essay to the Guide, pp. xxii-xxiii. 